Larysa SARKISIAN, Mariia VARLAMOVA

\title{
TRENDS IN THE DEVELOPMENT OF GLOBAL CITIES: ENVIRONMENTAL ASPECTS
}

\begin{abstract}
Conceptual approaches to the definition of global cities are studied. The formation of global cities is analysed by regions. After an analysis of the world rankings of global cities, the author determines that the five leading cities - New York, London, Paris, Tokyo and Hong Kong - have remained unchanged in recent years. An assessment of global initiatives to stimulate cities to implement environmental policy is given. The strategy of sustainable development of one of the global cities is considered on the example of Sydney and its integrated environmental development. The experience of the largest Ukrainian cities in the formation of environmental priorities in their development strategies is studied.
\end{abstract}

(C) Larysa Sarkisian, Mariia Varlamova, 2020.

Sarkisian Larysa, Candidate of Economic Sciences, Associate Professor at the Department of World Economy, Kyiv National University of Trade and Economics, Ukraine. ORCID: 0000-0003-3030-5000, Email: I.sarkisian@knute.edu.ua

Varlamova Mariia, Candidate of Economic Sciences, Associate Professor at the Department of International Economic Relations, Vasyl' Stus Donetsk National University, Ukraine. ORCID: 0000-00017111-1136, Email: m.varlamova@donnu.edu.ua 


\section{Key words:}

global city, ecological transformations, urbanization, sustainable development, strategy, agglomeration.

JEL: F64.

\section{Literature review and problem statement}

Creation of global economic networks contributes to the spread and deepening of globalization processes, for which cities are the main drivers of economic growth and development. Modern cities are being transformed into new centres for attracting investment, innovation and knowledge exchange, adapting best practices in governance and international management. If the cities make use of the synergy effects, it allows them to become independent players in the international political, economic and cultural spheres.

Leading scientific schools have formed a fairly broad terminological apparatus to define the concept of global cities, which define cities as: centres of economic activity, decision-making centres, centres of information and technological networks, centres of best practices in cultural and social spheres, etc.

The author of the term "global cities», Saskia Sassen (2005), defines its model based on 7 hypotheses:

- geographic dispersal of economic activities;

- headquarters of global companies increasingly outsource their central functions;

- synergy of firms, talents and expertise transform an urban environment into an information centre;

- highly specialised and networked service sector;

- development of cross border city-to-city transactions and networks and transnational urban systems;

- growing informalization of economic activities. 
Ukrainian researcher I. Skavronska (2014) notes that global cities are urban conglomerates, through which all economic activity (financial relations, international trade, political power, latest technologies, organization of sports megaevents) in the world spreads.

According to A. Demicheva (2016), global cities are those that have been the quickest and most successful in their adaptation to the conditions of a globalized space, where the concentration of capital and resources of various kinds (including opportunities) is the largest and those, which occupy a dominant position in the world.

Researchers O. Pyroh and Y. Maksymchuk (2017) propose to consider global cities in terms of economic, political, ideological and logistical approaches. The economic approach considers the global city as one where economic processes are concentrated and managed. Within the political approach, global cities are presented as national centres that direct international forces and influence them in favour of national interests. The ideological approach involves looking at the city as a "centre of power» and a "centre of decision-making that does not necessarily coincide with the capital or city of the nation». The logistics approach is based on the concept of forming various world flows.

Signs of global cities, regardless of their territorial location include (Clark, 2016):

1. active participation in international events;

2. a large population;

3. developed transport infrastructure;

4. location of international financial and legal organizations, corporate headquarters, stock exchanges;

5. world renowned cultural and educational institutions, sports clubs, lively cultural and sports life;

6. attracting both citizens of the country and foreign tourists;

7. backbone of the economic system - complex services;

8. multiculturalism.

Thus, global cities are points of concentration of economic, institutional, human and cultural capital, which form as gravity wells for investment, innovation and migration flows, with extensive infrastructure and a developed system of governance with a population of over 10 million people.

Modern problems of urban development are inextricably linked with two pressing issues: economic stability and the environment. Today the exacerbation of environmental problems, planetary climate change and the challenges facing society oblige us to rethink existing approaches to urban development, to adjust our strategies so as to find a balance between economic, technological, social and environmental priorities. 
The COVID-19 pandemic has created additional risks to the effective functioning of global cities, as population density and urban infrastructure can contribute to the exponential spread of disease, which changes the attractiveness of global cities for the population. Certain questions posed by the pandemic and the response of the authorities and enterprises have led to the spread of remote work, and as a result, a large part of the working population considers safety in the context of the spread of the virus as one of the main factors in choosing a place to live. Thus, there is a change in priorities, which may affect the pace of urbanization and related trends in the future.

\section{The aim of the research}

The purpose of the article is to identify trends in the development of global cities with priority consideration of environmental issues

\section{Research methods}

The research was conducted through methods of analysis and synthesis, induction and deduction, economic and statistical methods. The application of the method of systematization made it possible to generalize the world experience and determine trends in global cities. The conceptual approaches to the creation of strategies of global cities were studied using the abstract-logical method of economic research. Although the methods of economic and mathematical modelling are usually invaluable, their use was impossible in the context of the chosen direction of research due to the different approaches of countries to measuring the results of the implementation of urban strategies, in particular, the environmental component.

\section{Research results}

The author of the book Global Cities: A Short History, Greg Clark, notes that the development of global cities might be put at risk «... if cities lose competitiveness in traded sectors, fail to embrace innovation or to project influence, are closed to immigration and entrepreneurship, or are unable to adapt to a changing geopolitical or geoeconomic centre of gravity" (Clark, 2016). Such risks are high for both modern cities and the global cities of the future. 
The authors of another study maintain that the key to achieving high economic, social and environmental results lies not in the growth of cities in size, but in achieving efficiency in such areas as direct air connections to major destinations, while high-speed Internet and extensive modern infrastructure are crucial for integration into the global economy (Kotkin et al., 2014).

According to World Bank experts, more than 4 billion people around the world now live in cities (more than half of the world's population). According to forecasts, in 2050, with a doubling of the urban population, approximately 7 out of 10 people will live in cities. More than $80 \%$ of world GDP will be generated in cities, so urbanization will be able to make a significant contribution to sustainable growth given that quality governance is ensured through increased productivity and opportunities created for the development of new ideas and innovations (The World Bank, 2020). According to scientists, in 2035 the GDP of the largest cities will exceed the GDP of some countries. In particular, New York's GDP will be 2.5 trillion USD, that of Los Angeles - 1.5 trillion USD, London's - 1.3 trillion USD, Shanghai's - 1.3 trillion USD. In 2019, Tokyo became the leader among global cities with a GDP of 1.6 trillion USD (Muggah, 2020). Thus, the economic capacity of individual cities will create the preconditions for the creation of integrated and coordinated policies in the leading areas between them, improving the management of global capital flows, information, labour and technology and, consequently, reducing global imbalances.

The rapid development of urban agglomerations over the past 30 years has contributed to the emergence of cities with a dense population of more than 10 million people. The largest number of such cities is concentrated in Southeast Asia and sub-Saharan Africa (Fig. 1).

The concentration of so many cities in these regions creates additional governance and administration challenges for the communities and regional authorities, as well as the central governments of these countries. However, at the same time, new opportunities for growth emerge through the involvement of local and global companies, international organizations and financial institutions, thus creating synergetic effects.

A new trend towards rapid urbanization is apparent in China in the increase in the number of cities with population of more than one million people, which are attracting innovation, investment and rapid industrial development. The GDP of these cities is equal to the GDP of small European countries such as Bulgaria and Romania.

Most often, the growth of these cities is facilitated by the joint efforts of national, regional and local governments to increase the competitiveness of the country as a whole and cities in particular. These initiatives most often focus on entrepreneurial, governmental, and cultural activities that improve residents' quality of life, ease of doing business, and attract investment and attention from global companies. 
Figure 1

\section{Emergence of urban agglomerations in 1990-2018}

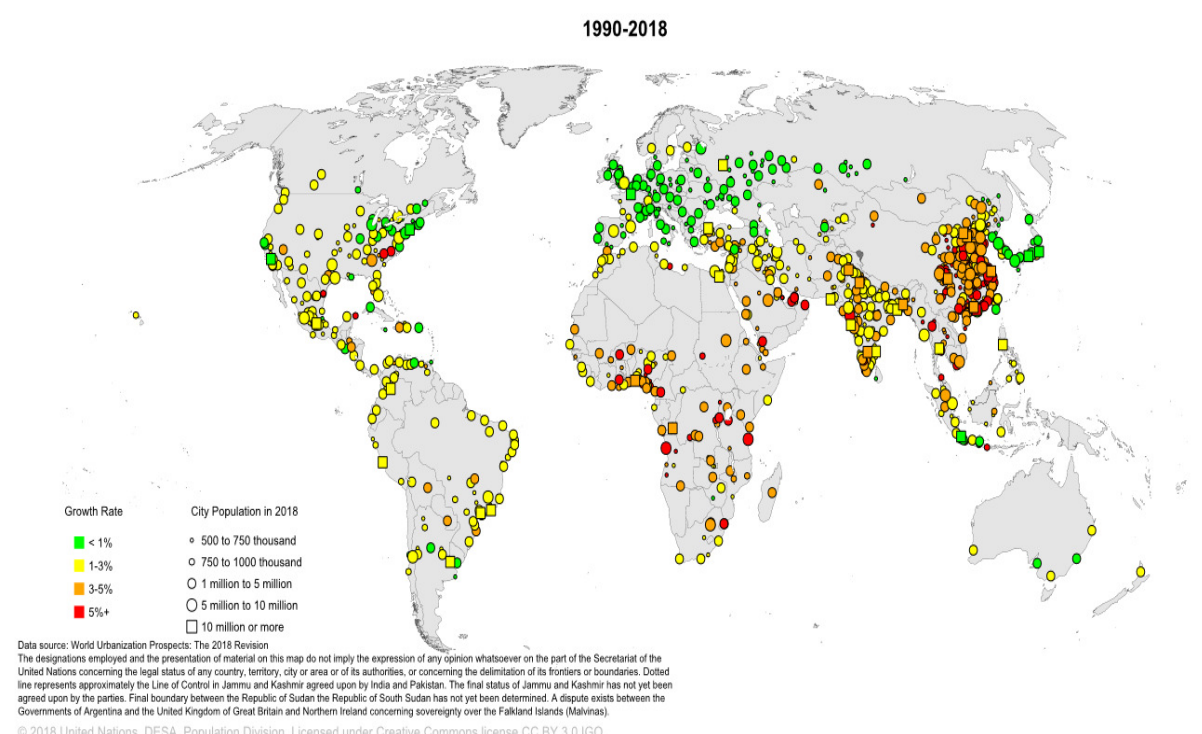

Source: Department of Economic and Social Affairs (2018). World Urbanization Prospects 2018 [Interactive map]. United Nations. https://population.un.org/wup/Maps/

Given the role of cities in global development, their impact and potential, each year an index of global cities is compiled, which measures the degree of their globalization and impact. The Global city index is an aggregate indicator compiled by the consulting company ATKearney. The index takes into account indicators of the level of business activity, human capital, information exchange, cultural experience, and political involvement (Table 1).

The Global Cities Report assessed 130 cities by the following aggregates: business activity (30\%), human capital (30\%), information exchange (15\%), cultural experience $(15 \%)$, and political involvement (10\%).

The authors of the report concluded that the level of human capital development will be crucial for the development of these cities, and will allow them to become global hubs for attracting people, technology, investment, etc.. For the third year in a row, New York, the world's financial and economic center, is in the lead. The highest-ranking European city is London (2nd place), Asian city - Tokyo (4th place), Australian city - Sydney (11th place, an increase of 6 positions compared to 2017). African cities are not yet in the first group of 25 countries, but they have significant potential for growth. 
Table 1

Rating of leading cities in the Global city index (2017-2019)

\begin{tabular}{|c|l|c|c|c|c|l|c|c|c|}
\hline No & \multicolumn{1}{|c|}{ City } & 2019 & 2018 & 2017 & No & \multicolumn{1}{|c|}{ City } & 2019 & 2018 & 2017 \\
\hline 1 & New York & 1 & 1 & 1 & 11 & Washington & 10 & 11 & 10 \\
\hline 2 & London & 2 & 2 & 2 & 12 & Seoul & 13 & 12 & 12 \\
\hline 3 & Paris & 3 & 3 & 3 & 13 & Madrid & 15 & 13 & 13 \\
\hline 4 & Tokyo & 4 & 4 & 4 & 14 & Moscow & 18 & 14 & 18 \\
\hline 5 & Hong Kong & 5 & 5 & 5 & 15 & Sydney & 11 & 15 & 17 \\
\hline 6 & Los Angeles & 7 & 6 & 8 & 16 & Berlin & 14 & 16 & 14 \\
\hline 7 & Singapore & 6 & 7 & 6 & 17 & Melbourne & 16 & 17 & 15 \\
\hline 8 & Chicago & 8 & 8 & 7 & 18 & Toronto & 17 & 18 & 16 \\
\hline 9 & Beijing & 9 & 9 & 9 & 19 & Shanghai & 19 & 19 & 19 \\
\hline 10 & Brussels & 12 & 10 & 11 & 20 & San Francisco & 22 & 20 & 23 \\
\hline
\end{tabular}

Source: compiled by the author on the basis of data from A.T. Kearney $(2018 ; 2019)$.

Cities have transformational potential as urban laboratories. Cities are intellectual and innovative hubs that are able to generate new ideas and concepts. Experimenting in cities results in positive outcomes, but at the same time demonstrates the problems and issues that still need to be addressed. This is part of an important process in which hands-on learning is a fundamental component of adaptive, flexible and sustainable planning (Marketplace of the European Innovation Partnership on Smart Cities and Communities, 2018).

Accelerating pace of urbanisation in all countries and the developing pool of booming cities and large agglomerations with over 10 million residents create potential economic opportunities for companies and citizens, but at the same time increases the burden on the environment. This creates additional incentives for local governments to take the environmental factor into account in the city's development strategy.

Cities offer ample opportunities for economic development and for expanding access to basic services, including health and education for a large number of people, but all this is subject to good governance. The provision of public transport services, as well as housing, electricity, water and sanitation for densely populated urban residents is generally cheaper and less harmful to the environment. (Honchar, 2014).

The fourth industrial revolution sets new challenges and opportunities for the development of global cities. Digitization of production processes, the formation of new value chains, harmonization of economic and environmental inter- 
ests, recycling of materials, and prevalence of technology on all stages of the production cycle create additional impetus for the development of global cities.

Accordingly, the role of global cities is getting re-defined in the face of growing environmental challenges. Cities are becoming drivers of change and developers of best practices for integrating environmental initiatives into strategic vision programs. Tackling environmental challenges at the level of cities and agglomerations allows the authorities to form sustainable mechanisms for regulating their impact on economic and social development. Environmental issues at the urban level may include climate change, waste management, reduction of CO2 emissions, expansion of green zones, resource management, and others.

Experts of the World Economic Forum note that in the face of rapid depletion of natural resources, environmental degradation is a threat to human wellbeing. Modern cities are full of pollutants, traffic and noise. Accordingly, for example, a modern urban landscaping system can be one of the means of reducing epidemics of non-communicable diseases, environmental degradation and air pollution, primarily through its accessibility to cities with different levels of economic development (Muggah \& Katz, 2020).

The global COVID 19 pandemic has increased the need for a stimulating and effective environmental policy, as an unfavorable environmental situation creates increased risks. According to Health Affairs, the death rate in some global cities is higher than the national average. For example, at the end of April, New York (3\% of the US population) accounted for $20 \%$ of deaths from COVID19 in the US; in London (14\% of the UK population) it was 33\%; in the Paris region lle-de-France $(18.6 \%$ of the population of France) $-25 \%$, Tokyo $(11 \%$ of the population of Japan) accounted for 30\% (Rodwin \& Gusmano, 2020).

Seoul, Singapore and Taipei have successfully mitigated the effects of the pandemic through a prompt response and efficient use of various tools, including wide testing and detection systems, a sufficient number of medical professionals, good medical and transport infrastructure, and communication technologies, thus demonstrating the importance of high managerial capacity (Muggah \& Katz, 2020). If other global cities review such exemplary practices, they can take advantage of previous experiences to find their own unique way to overcome the effects of the pandemic and incorporate prevention tools into long-term development strategies. Note that the above-mentioned Asian cities relied on previous management experience in overcoming the epidemic of SARS and other infectious viral diseases.

Accordingly, environmental policy should reflect the priorities for municipal initiatives, consist of quantitative and qualitative indicators, and determine the expected outcomes, including reduction of the morbidity rate through environmental improvements. 
The effectiveness of the city's environmental policy, built into the overall concept of city development, determines its competitiveness in the world economic system and its functioning as an innovation and technological hub. The authors of the study conducted in 2017 examined the leading global cities in terms of their environmental policy and grouped them into 4 clusters: cities with good environmental policies (Frankfurt am Main, Los Angeles, Taipei, etc.); cities with a high level of welfare (Zurich, Singapore, Washington, etc.); outsider cities (Moscow, Jakarta, Boston) and cities with problematic environmental policies (Beijing, Toronto, New York, etc.) (Kozuik et al., 2017).

Despite the leading economic, financial and political positions of the above-mentioned cities, the state of the environment is a significant risk factor in these cities and, accordingly, the focus of local governments. The Global Risks 2020 report considers environmental risks to be the most significant, including climate change, weather change, biodiversity loss, anthropogenic environmental disasters and natural disasters. (World Economic Forum, 2020).

The increasing environmental risks are monitored by leading international organizations, including the United Nations (UN), which is one of the pioneers in the development of strategically important documents and action plans for effective solutions to environmental problems.

The final declaration of the First UN-HABITAT Assembly, organized in 2019 , described the present period of human history as an «unprecedented era of growing urbanization", which is a problem and at the same time an opportunity to promote sustainable development in urban and rural areas. The Declaration draws attention to such key objectives as the reduction of spatial inequality and poverty in cities; increasing the overall welfare of cities by increasing their innovation potential and enabling them to act as centres of innovation; improving the urban environment and environmental sustainability of cities; effective prevention and response to urban crises.

The Global Sustainable Development Goals, designed and approved by the UN in 2015, include a list of 17 goals needed to build a foundation for sustainable development in countries and regions. The $11^{\text {th }}$ Sustainable Development Goal is concerned with ensuring openness, security, and environmental sustainability of cities and settlements, due to the growing importance of cities in a rapidly globalized world.

The main areas of sustainability are defined within the framework of the sustainable urban development concept. They determine the development of urban strategic planning using such benchmarks as social development, economic development, environmental management and urban governance (Fig. 2). 
Figure 2

Main directions of achieving urban sustainability

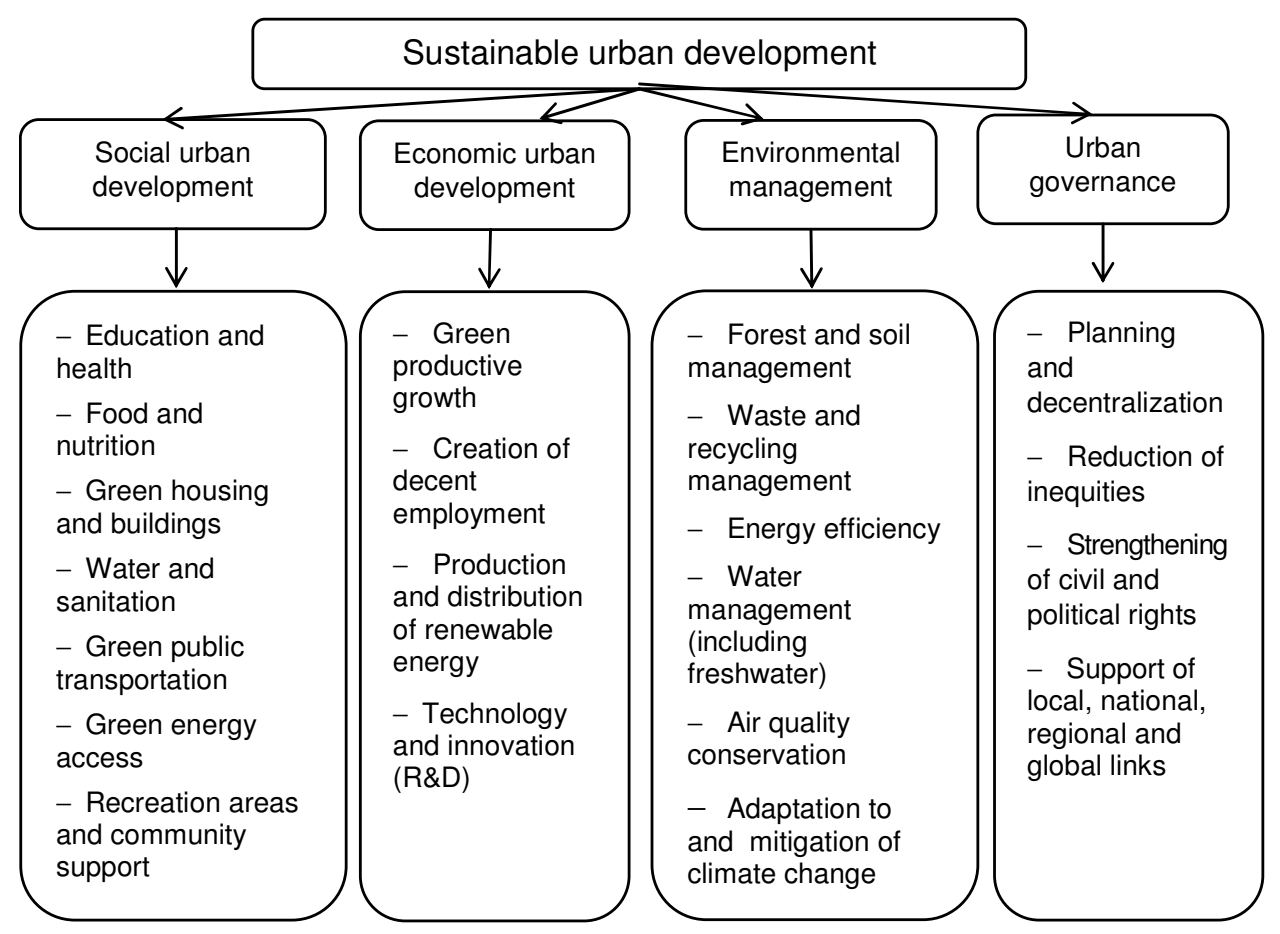

Source: adapted from Department of Economic and Social Affairs. (2013). United Nations.https://www.un.org/en/development/desa/policy/wess/wess_current/wess2013/Chapt er3.pdf

In order to determine the priority and effectiveness of sustainable development policy, global cities are preparing a Voluntary Local Review - a report on the implementation of global goals of sustainable development, which expounds upon the achieved progress and the used tools.

Such reports are prepared by New York, Los Angeles, Buenos Aires, Taipei, which proves the high level of interest of local governments and other stakeholders in the implementation of environmental goals on a local and global scale, setting a positive example for other global cities.

The main tool for achieving the Sustainable Development Goals at the city level is the strategy of city development. Cities Alliance (n.d.) defines a city development strategy as an action-oriented process developed and supported 
through participation to promote sustainable growth in cities and surrounding regions to improve the quality of life of all citizens.

The city development strategy may be aimed at increasing the economic and social capacity of the city based on positive environmental transformations and common values of stakeholders. The city development strategy should promote development of partnerships and implementation of joint initiatives, introduction of open data policy and appropriate information support, as well as enactment of sustainable practices at the local level. Creation of technological hubs and centres of knowledge can serve as a foundation for further transformations. The implementation of the strategy may result in the improvement of the city's transport infrastructure, increase in the number of green areas, effective waste management policy, implementation of environmental building codes, improvement of air quality.

The World Cities Report 2016 offers a set of tools for the implementation of sustainable development in cities (Table 3).

Three levels of policy intervention are identified, as well as meaningful examples and objectives for their achievement. For example, at the level of management tools, environmental budgets and audits according to international standards can be implemented, which will increase the accountability of environmental management and areas of variability.

The experience of successful strategic planning and implementation of environmental principles in the development of global cities has been accumulated in Sydney, where the strategy of sustainable development Sustainable Sydney 2030 was created in 2008. Its main principles are summarised in Table 4.

The strategy is based on 7 strategic areas (resilient Sydney, digital city, business and economy, communities and culture, sustainability, architecture and design, transport and access) and 10 priorities, each of which is clear and easily measurable. The city development programs are subject to a 10-year long-term plan, a 4-year medium-term plan and a 1-year operational plan (Hu, 2015).

The results of the Strategy are measured by more than 100 indicators; reports are prepared for every six-month, one-year and four-year period. Thus, the implementation of the Strategy should contribute to the formation of an inclusive economic system capable of meeting the challenges of modern global development and environmental change (especially climate, which is already acutely felt by Australia in general and Sydney in particular).

Analysing the Ukrainian experience, it should be noted that none of the big cities is among the leading global cities. However, the cities' development strategies notably include the environmental component. In particular, Kyiv Development Strategy 2025 identifies sustainable development as one of the five key development priorities, which provides for a balance of economic, social and environmental components. 
Table 3

Tools for implementing sustainable development policy in cities

\begin{tabular}{|c|c|c|c|}
\hline $\begin{array}{l}\text { Type of in- } \\
\text { tervention }\end{array}$ & $\begin{array}{l}\text { Type of in- } \\
\text { strument }\end{array}$ & Examples & Objectives \\
\hline \multirow{4}{*}{ Policy } & Information & $\begin{array}{l}\text { Training, research and } \\
\text { awareness campaigns }\end{array}$ & $\begin{array}{l}\text { Produce and share envi- } \\
\text { ronmental information }\end{array}$ \\
\hline & Voluntary & $\begin{array}{l}\text { Codes, labelling, au- } \\
\text { dits }\end{array}$ & $\begin{array}{l}\text { Incentives for eco-friendly } \\
\text { behaviour }\end{array}$ \\
\hline & Economic & Taxes or subsidies & $\begin{array}{l}\text { Account for environmental } \\
\text { costs of certain activities }\end{array}$ \\
\hline & Regulatory & $\begin{array}{l}\text { Controls, bans, quo- } \\
\text { tas, licensing, stan- } \\
\text { dards }\end{array}$ & $\begin{array}{l}\text { Applicable to specific out- } \\
\text { come }\end{array}$ \\
\hline \multirow{3}{*}{$\begin{array}{l}\text { Process } \\
\text { instru- } \\
\text { ments }\end{array}$} & $\begin{array}{l}\text { Developing a } \\
\text { vision }\end{array}$ & $\begin{array}{l}\text { Events bringing to- } \\
\text { gether various stake- } \\
\text { holders }\end{array}$ & Develop a city vision \\
\hline & $\begin{array}{l}\text { Baseline } \\
\text { studies }\end{array}$ & $\begin{array}{l}\text { Background studies of } \\
\text { a city }\end{array}$ & $\begin{array}{c}\text { Understanding current } \\
\text { neighbourhood or city } \\
\text { conditions }\end{array}$ \\
\hline & $\begin{array}{l}\text { Development } \\
\text { priorities }\end{array}$ & $\begin{array}{c}\text { Dialogue forums and } \\
\text { consensus confer- } \\
\text { ences }\end{array}$ & $\begin{array}{l}\text { Ensure an open definition } \\
\text { of multiple priorities and } \\
\text { contrasting values that will } \\
\text { inform the planning process }\end{array}$ \\
\hline \multirow{4}{*}{$\begin{array}{l}\text { Planning } \\
\text { instru- } \\
\text { ments }\end{array}$} & $\begin{array}{l}\text { Environ- } \\
\text { mental profile }\end{array}$ & $\begin{array}{l}\text { Systematic analysis of } \\
\text { background environ- } \\
\text { mental conditions in a } \\
\text { given area }\end{array}$ & $\begin{array}{l}\text { Provide a common under- } \\
\text { standing of city sectors in- } \\
\text { teraction with the environ- } \\
\text { ment and governance }\end{array}$ \\
\hline & $\begin{array}{l}\text { Environmental } \\
\text { footprint and } \\
\text { targets } \\
\end{array}$ & $\begin{array}{l}\text { Resource footprinting } \\
\text { Material flows analy- } \\
\text { sis }\end{array}$ & $\begin{array}{l}\text { Assess the city's ecologi- } \\
\text { cal carrying capacity }\end{array}$ \\
\hline & $\begin{array}{c}\text { Impact as- } \\
\text { sessment } \\
\text { tools }\end{array}$ & $\begin{array}{c}\text { Strategic Impact or } \\
\text { Sustainability As- } \\
\text { sessment }\end{array}$ & $\begin{array}{l}\text { Assess the impact of } \\
\text { specific policies and pro- } \\
\text { grammes }\end{array}$ \\
\hline & $\begin{array}{l}\text { Monitoring } \\
\text { systems and } \\
\text { indicators } \\
\end{array}$ & $\begin{array}{l}\text { Systems to take } \\
\text { measurements at } \\
\text { regular intervals }\end{array}$ & $\begin{array}{c}\text { Specify progress against } \\
\text { objectives and revise the } \\
\text { planning process }\end{array}$ \\
\hline $\begin{array}{l}\text { Manage- } \\
\text { ment in- } \\
\text { struments }\end{array}$ & $\begin{array}{l}\text { Environ- } \\
\text { mental budg- } \\
\text { ets and audits }\end{array}$ & $\begin{array}{l}\text { EcoBudget, EMAS or } \\
\text { ISO } 14001\end{array}$ & $\begin{array}{l}\text { Periodic revision of envi- } \\
\text { ronmental management } \\
\text { procedures }\end{array}$ \\
\hline
\end{tabular}

Source: adapted from UN-Habitat. (2016). World Cities Report 2016: Urbanization and Development - Emerging Futures. https://www.sdgfund.org/world-cities-report-2016urbanization-and-development-\%E2\%80\%93-emerging-futures 
Table 4

Main principles of Sydney's sustainable development strategy Sustainable Sydney 2030

\begin{tabular}{|c|c|c|}
\hline Strategic area & Description & Priorities \\
\hline Resilient Sydney & $\begin{array}{l}\text { Ability to meet the } \\
\text { challenges of the } 21 \mathrm{st} \\
\text { century }\end{array}$ & $\begin{array}{l}\text { Reduce carbon emissions by } \\
50 \% \text { (compared to 1990) }\end{array}$ \\
\hline Digital city & $\begin{array}{l}\text { Increasing competi- } \\
\text { tiveness in the digital } \\
\text { world }\end{array}$ & $\begin{array}{l}\text { Develop the capacity of local re- } \\
\text { sources to meet the need in elec- } \\
\text { tricity and water supply }\end{array}$ \\
\hline $\begin{array}{c}\text { Business and econ- } \\
\text { omy }\end{array}$ & $\begin{array}{l}\text { Promoting economic } \\
\text { development }\end{array}$ & Build 48,000 residential buildings \\
\hline $\begin{array}{l}\text { Communities and } \\
\text { culture }\end{array}$ & $\begin{array}{l}\text { Everyone can enrich } \\
\text { the culture of Sydney }\end{array}$ & $\begin{array}{l}45 \% \text { of the population believe } \\
\text { that the majority of citizens are } \\
\text { trustworthy }\end{array}$ \\
\hline Sustainability & $\begin{array}{l}\text { Sydney's contribution } \\
\text { to a sustainable fu- } \\
\text { ture }\end{array}$ & $\begin{array}{l}\text { Creation of } 97,000 \text { jobs in ag- } \\
\text { glomeration centres }\end{array}$ \\
\hline $\begin{array}{c}\text { Architecture and } \\
\text { design }\end{array}$ & $\begin{array}{l}\text { Support of elevating } \\
\text { design standards }\end{array}$ & $\begin{array}{l}7.5 \% \text { of the construction fund for } \\
\text { social purposes (of the total) }\end{array}$ \\
\hline \multirow{4}{*}{$\begin{array}{l}\text { Transport and ac- } \\
\text { cess }\end{array}$} & \multirow{4}{*}{$\begin{array}{l}\text { Integrated transport } \\
\text { plans for the prosper- } \\
\text { ity of the city }\end{array}$} & $\begin{array}{l}80 \% \text { of employees use public } \\
\text { transport }\end{array}$ \\
\hline & & $\begin{array}{l}10 \% \text { of strolls through the city are } \\
\text { done by bike ( } 50 \% \text { on foot) }\end{array}$ \\
\hline & & $\begin{array}{l}\text { Enable the locals to reach the } \\
\text { main street in } 10 \text { minutes }(800 \mathrm{~m})\end{array}$ \\
\hline & & $\begin{array}{l}\text { Create an opportunity for every } \\
\text { local to walk in the green areas } \\
\text { for } 3 \text { minutes }(260 \mathrm{~m})\end{array}$ \\
\hline
\end{tabular}

Source: compiled by the author on the basis of data from Hu, R. (2015).

The development strategies of the biggest Ukrainian cities are peculiar, as they seemingly include the environmental component in their overall makeup and integrate it with the other components, yet do not implement the comprehensive strategies of sustainable development prevalent in the world practice. Sime progress is already being made in this direction, for instance the city of Kyiv plans to finalise its eco-strategy in 2020. This strategy will consist of five areas: "air», "water», "waste», "green areas and biodiversity», "education and science». If it is successfully implemented, it can become an inspiration for other cities. 


\section{Conclusion}

Urban development contributes to the increase of business activity of cities, attraction of innovations, development of human capital, but at the same time creates preconditions for rapid ecological changes, the impact of which can be studied and analysed in decades. Accordingly, the inclusion of environmental measures in the overall urban development strategy will reduce the potential negative impact and positively affect the quality of life in the long term. The experience of forming strategies of global cities demonstrates the existence of clearly defined goals of sustainable development, priorities and mechanism for their implementation. Further research can be conducted to study the trends and features of the creation and implementation of the environmental component of the global city strategies in developing countries.

\section{References}

1. A.T. Kearney. (2018). Global Cities Report 2018. https://www.atkearney.com/ global-cities/2018

2. A.T. Kearney. (2019). Global Cities Report 2019. https://www.atkearney.com/ global-cities/2019

3. Bhatnagar, A. (2019, September 16). Greenery: The miracle cure for urban living. World Economic Forum. https://www.weforum.org/agenda/2019/09/ greenery-the-miracle-cure-for-urban-living/

4. Cities Alliance. (n.d.). What is a City Development Strategy and what are its benefits? http://city-development.org/intro/

5. Clark, G. (2016, December 1). How cities took over the world: A history of globalisation spanning 4,000 years. The Guardian. https://www.theguardian.com/cities/2016/dec/01/how-cities-took-over-theworld-a-history-of-globalisation-spanning-4000-years

6. Demicheva, A. V. (2016). The global cities and their positioning in area of modern international relations [in Ukrainian]. Young Scientist, 2, 241-245. http://nbuv.gov.ua/UJRN/molv_2016_2_59

7. Department of Economic and Social Affairs. (2013). World Economic and Social Survey 2013. United Nations. https://www.un.org/en/development/ desa/policy/wess/wess_current/wess2013/Chapter3.pdf 
8. Department of Economic and Social Affairs. (2018). World Urbanization Prospects 2018 [Interactive map]. United Nations. https://population.un.org/ wup/Maps/

9. Honchar, O. M. (2014). The necessity of implementation of the concept for sustainable development in Ukrainian cities [in Ukrainian]. Global and $\mathrm{Na}$ tional Problems of Economics, 2, 181-185. http://global-national.in.ua/ archive/2-2014/37.pdf

10. Hu, R. (2015). Sustainable development strategy for the global city: A case study of Sydney. Sustainability, 7(4), 4549-4563. https://doi.org/10.3390/ su7044549

11. Kotkin, J., Cox, W., Modarres, A., \& Renn, A. M. (2014). Research Report for the Seminar Organised by Civil Service College, on Size is Not the Answer: The Changing Face of the Global City. Civil Service College. https://www.chapman.edu/wilkinson/_files/the-changing-face-of-the-globalcity.pdf

12. Koziuk, V. V., Hayda, Y. I., \& Shymanska, O. P. (2017). Urban-centric view on environmental measurement of the welfare of the state [in Ukrainian]. Ekonomichnyi analiz, 27(3), 37-48.

13. Marketplace of the European Innovation Partnership on Smart Cities and Communities. (2018). Towards a joint investment programme for European smart cities. https://eu-smartcities.eu/sites/default/files/2018-06/EIP-SCC_ TOWARDS\%20A\%20JOINT\%20INVESTMENT-Paper.pdf

14. Muggah, R. (2020). Look to cities, not nation-states, to solve our biggest challenges. World Economic Forum Annual Meeting 2020. https://www.weforum.org/agenda/2020/01/cities-mayors-not-nation-stateschallenges-climate/

15. Muggah, R., \& Katz, R. (2020, March 17). How cities around the world are handling COVID-19 - and why we need to measure their preparedness. World Economic Forum. https://www.weforum.org/agenda/2020/03/howshould-cities-prepare-for-coronavirus-pandemics/

16. Pyroh, O.V., \& Maksymchuk, Y. S. (2017). Conceptual foundations of global cities: Scientific approaches to defining the essence [in Ukrainian]. Visnyk of Dniprop'etrovsk University. Ser. World Economy and International Economic Relations, 25(9), 59-69.

17. Rodwin, V. G., \& Gusmano, M. K. (2020, June 24). World cities and national policy in the time of COVID-19. Health Affairs. https://www.healthaffairs.org/ do/10.1377/hblog20200618.523168/full/

18. Sassen, S. (2005). The global city: Introducing a concept. Brown Journal of World Affairs, 11(27), 27-43. http://www.saskiasassen.com/pdfs/ publications/ theglobal-city-brown.pdf 
19. Skavronska, I. (2014). World and global cities: Similarities and differences [in Ukrainian]. Skhid, 4(130), 61-64. http://skhid.kubg.edu.ua/article/ view/26690/ 24235

20. The World Bank. (2020, April 2020). Urban development overview. https://www.worldbank.org/en/topic/urbandevelopment/overview

21. Ukrainian Institute of Strategies of Global Development and Adaptation. (2019, June 3). "Sustainable Urbanization» - First UN Habitat Assembly [in Ukrainian]. https://uisgda.com/ua/ustojchivaya-urbanizaciya-pervaya-assambleyaoon-habitat.html

22. UN-Habitat. (2016). World Cities Report 2016: Urbanization and Development - Emerging Futures. https://www.sdgfund.org/world-cities-report-2016urbanization-and-development-\%E2\%80\%93-emerging-futures

23. World Economic Forum. (2020). The Global Risks Report 2020. http://www3.weforum.org/docs/WEF_Global_Risk_Report_2020.pdf 